\title{
ТЕСТУВАННЯ РІВНЯ БЕЗПЕКИ ПРОТОКОЛУ IPV6
}

\begin{abstract}
Анотація: у статті описано створення тестової лабораторії для дослідження рівня безпеки мережевого протоколу IPv6 та запропоновано методи, спрямовані на підвищення рівня безпеки комп'ютерних мереж, що використовують IPv6. Проведено аналіз заходів безпеки та їх реалізації на обладнанні Cisco та Juniper.

Ключові слова: комп'ютерна мережа, рівень безпеки, вразливості, тестування рівня безпеки, протокол ICMPv6, протокол IPv6.
\end{abstract}

\section{Вступ}

Процес впровадження мережевого протоколу нового покоління IPv6 відбувається поступово протягом останніх років (Всесвітній запуск якого відбувся 6 червня 2012 року). Але, темпи розвитку всесвітньої мережі Інтернет, значно вищі, що стимулює прискорення переходу на IPv6.

Одна із перешкод, що необхідно подолати е страх перед невідомим, так як переналаштування обладнання для роботи з новим протоколом може призвести до непередбачуваних наслідків, зокрема при одночасній роботі з $\operatorname{IPv} 4$. Окрім цього, для забезпечення надійного розгортання мережевого протоколу IPv6 необхідно акцентувати увагу на проблемах безпеки. При розробці протоколу IPv4 це був далеко не основний критерій, тому він мав багато вразливостей. 3 огляду на те, що протокол $\mathrm{IPv} 4$ використовувався протягом багатьох років, більшість недоліків, що йому притаманні усувались по мірі їх виявлення, і ці практики добре себе зарекомендували. Тa, на час впровадження IPv4, мережі були досить невеликі, і це було не так критично, враховуючи масштаби сучасних мереж, подібні помилки можуть призвести до серйозніших наслідків.

Ця робота допоможе відповісти на важливе питання, чи справді в протоколі IPv6 реалізовано рівень безпеки, який відповідає сучасним вимогам? Для цього зібрано наявну на сьогоднішній день інорормацію про реалізацію безпеки протоколу IPv6, що спираеться на досвід, накопичений через використання IPv4. Загрози та виявлені вразливості протоколу розглядаються на обладнанні Cisco та Juniper. Запропоновані заходи щодо підвищення безпеки перевіряються у тестовій лабораторії.

\section{Постановка задачі}

Статистичні дані свідчать, що протокол мережевого рівня IPv6 e не досить розповсюдженим. Лише $14 \%$ провайдерів завершили його впровадження у своїх мережах і лише $4 \%$ почали пропонувати

(c) В.П. Пасько, Ю.О. Халавчук, 2015 
IPv6 своїм кінцевим користувачам [1]. На сьогодні безпека протоколу IPv6 е однією з основних проблем, що гальмують його поширення. Оскільки на даний момент цей протокол не використовуеться в мережах за замовчуванням (відбувається поступовий перехід з $\mathrm{IPv} 4$ на IPv6), немає ні найкращих практик та рекомендацій для мережевих адміністраторів, ні будь-яких гарантій, що реалізовані стеки протоколів IPv6 і методи забезпечення безпеки не мають помилок [2]. Це визначає необхідність дослідження його рівня безпеки. Задача полягає в організації тестової лабораторії для дослідження рівня безпеки протоколу IPv6 та реалізації заходів для їі підвищення.

\section{Різновиди атак}

Розгортання протоколу IPv6 відбувається одночасно із появою нових загроз безпеки кінцевих користувачів та їхніх даних. Загалом, проблеми безпеки пов'язані з протоколом IPv6 можна розділити на дві категорії: ті, що успадковані від його попередника - протоколу IPv4 та нові проблеми, пов'язані із новими можливостями, що були додані до протоколу. Деякі вразливості протоколу не враховані його специфікацією. Такі недоліки немож ливо усунути, при цьому не змінюючи сам протокол. Вирішення подібних проблем зазвичай лягає на плечі розробників.

Основні види атак та загрози, які варто розглянути.

- Розвідка в IPv6 лережі. Замість широкомовної розсилки протокол IPv6 використовуе групові повідомлення (multicast). I кожен вузол, що використовуе IPv6 стає членом хоча б однієї multicast групи, наприклад, FF02::1 (всі вузли локальної мережі). Зловмисник може використовувати дану особливість для пришвидшення фази розвідки.

- Перевантаження колутаторів. Максимальна кількість IPмаршрутів та MAC-адрес комутатора або маршрутизатора обмежуеться максимальним розміром САM і TCAM пам'яті. Включення маршрутизації IPv6 значно зменшуе загальну кількість записів ТСАМ. Це робить комутатор більш уразливими до (Т)САМ виснаження. Як результат, деякі платформи можуть переходити до процесорної обробки пакетів, викликаючи високе завантаження процесора або пересилати трафік через всі порти.

- Заголовки розширення. Заголовки розширення розміщуються між заголовком IPv6 та заголовком протоколу вищого рівня та містять у собі додаткову інформацію мережевого рівня. Ці заголовки використовуються для виконання таких функцій, як фррагментація, або для вказання проміжних пристроїв, через які повинен пройти пакет. Це доповнення протоколу може використовуватись зловмисником для проходження через систе- 
ми виявлення атак та мережеві екрани, а також для створення так званих “прихованих каналів” для передачі даних у заголовках розширення.

- Петля в лиарирутизаціi, при використанні IPv6 тунелів. Тунелювання використовується для передачі даних між островками, де використовується протокол IPv6, через мережу IPv4. Маршрутизатори, що знаходяться на кінцях тунелю працюють із обома протоколами і здійснюють передачу повідомлень, згідно особливостей протоколу тунелювання, що використовується. При використанні автоматичного тунелювання не відбувається перевірка наявності кінцевих точок тунелю. Зловмисник може використовувати це, надсилаючи пакет через вузол, що не є учасником тунелю в даний момент. В результаті, пакет пересилатиметься з тунелю знову, у нативну мережу IPv6. 3 цієї мережі, пакет направляється назад в точках входу в тунель. Таким чином пакет буде постійно передаватись в і з тунелю [4]. Жертвами такої атаки будуть вузли, що пересилають повідомлення з та в тунель.

- Атаки пов'язані з роботою ICMPv6. Протокол ICMPv6 є невід'ємною частиною протоколу IPv6. Він повідомляє про помилки та виконує діагностичні функції такі, як ping та traceroute, крім того, має базу для розширення та реалізації нових фрункцій. Процедура NDP - одна із вже реалізованих розширень, що повністю замінюе та удосконалює функції протоколу ARP, що працює в мережах з IPv4 [3]. На жаль, і велика частка атак пов'язана саме із цим протоколом.

- Виявлення однакових адрес. Даний механізм використовується кінцевими пристроями для того щоб запобігти появі двох однакових адрес всередині мережі. Він може використовуватись зловмисником для організації DoS атаки.

- Підліна повідоллення Router Advertisement (RA). У протоколі IPv6 реалізовано функцію автоматичного налаштування кінцевих пристроїв. Коли пристрої кінцевих користувачів надсилають запити на отримання мережевих налаштувань (на відміну від DHCP, запит іде на групову адресу), зловмисник може у відповідь надсилати свої налаштування, цим самим виконуючи DoS або MitM атаку.

- “Затоплення” RA повідолленняли.

Як і у попередньому випадку зловмисник підробляє RA повідомлення (можливо, додає нову інформацію про маршрут), але при цьому надсилає їх у великій кількості. Пристрій жертви перевантажується інформацією, що потребує обробки, вичерпуються ресурси. Тобто, ситуація призводить до відмови в обслуговуванні. 
- Підліна повідоллення Neighbor Advertisement (NA). Функція, що замінюе ARP, який використовуеться з протоколом IPv4. Зловмисник може видавати себе за "всі станції в локальній мережі, і тим самим виконуючи DoS або MitM атаку.

- “Затоплення” повідолленняли Neighbor Solicitation (NS). Функція, що практично не відрізняеться від ARP, який використовуеться з протоколом IPv4. Зловмисник може згенерувати велику кількість запитів на адресу жертви, тим самим перенавантажити інформацією, що потребуе обробки. Ресурси пристрою жертви вичерпуються, що призводить до відмови у обслуговуванні.

- Атаки пов'язані з роботою DHCPv6. Окрім автоматичного налаштування в мережі IPv6 також може використовуватись вже знайомий протокол DHCP нової версії. Як не дивно, нова версія має ті ж самі вразливості.

- Вичерпування простору адрес. Зловмисник може вичерпати простір вільних адрес на DHCPv6 сервері.

- Підліна DHCPv6 сервера. Зловмисник може видати себе за DHCPv6 сервер для здійснення DoS aбо MitM атаки.

\section{Аналіз атак}

Вказані атаки - це не весь список можливих небезпек, що можуть мати місце при використанні нового мережевого протоколу. Жертвами атак можуть бути як кінцеві користувачі, так і проміжне обладнання (маршрутизатори та комутатори).

При виконанні аналізу вразливостей можна виділити кілька категорій і врахувати приналежність однієї одразу до кількох із них. Виділено такі категорії:

- внутрішні - проблеми безпеки, що стосуються локальної мережi;

- зовнішні - проблеми безпеки, що стосуються глобальної (зовнішньої мережі);

- $D o S$ - проблеми безпеки, які можуть призвести до відмови в обслуговуванні;

- firewall - проблеми безпеки, пов'язані з мережевим екраном або іншими фільтруючими пристроями;

- приховані - проблеми безпеки, які дають можливість створення прихованого каналу зв'язку;

- розвідка - проблеми безпеки, пов'язані з виявленням адресної інформації кінцевих пристроїв;

- MitM - проблеми безпеки, які можуть бути використані для підключення до каналу передачі даних між його учасниками з метою перехвату, видалення або зміни інформаціі. 


\section{Розгортання тестової лабораторії}

Для розгортання тестової лабораторії використовувалось програмне забезпечення на базі Unix-систем, що дозволяє імітувати роботу комп'ютерної мережі з максимальним наближенням до реальної поведінки.

Використаний комплекс, дозволяє змоделювати віртуальну мережу, складовими частинами якої $є$ :

- лмарирутизатори;

- колутатори;

- персональні колп'ютери (кінцеві користувачі).

Для віртуалізації проміжного обладнання використано образи операційних системи cisco IOS та juniper junOS, тобто виконана повна емуляція обладнання. Для запуску віртуальних машин 3 операційною системою Windows 7, Windows 8 та Ubuntu використано утиліту VMware. Моделювання атак виконувалось за допомогою утиліти Scapy, що дає можливість створення та модифікації мережевих пакетів.

Вибрані топології для проведення тестування зображено на рис. 1 та рис. 2 для моделювання внутрішніх та зовнішніх атак відповідно.

При організації тестової лабораторії, розгортались окремі топології для перевірки обладнання кожного виробника. Приведемо приклад дослідження атак, на основі маніпуляцій із заголовками розширення.

На першому етапі тести виконувались при базовому налаштуванні проміжних пристроїв (без додаткових заходів безпеки). Здійснення атак відбувалось через окремий порт віртуального комутатора, до якого був доступ з комп'ютера, на якому розгорнуто топологію. На рис. 1 та рис. 2 цей комп'ютер зображено як Attacking host.

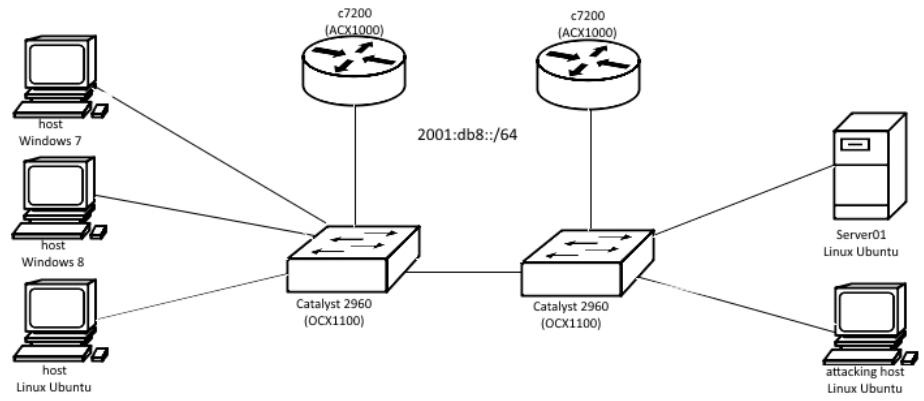

Рис. 1 - Топологія мережі для тестування внутрішніх атак 
Спершу розглядалась можливість створення "прихованого каналу" за допомогою опції $P a d N$, що знаходиться у заголовку розширення (Hop-by-Hop Extension Header та Destination Extension header).

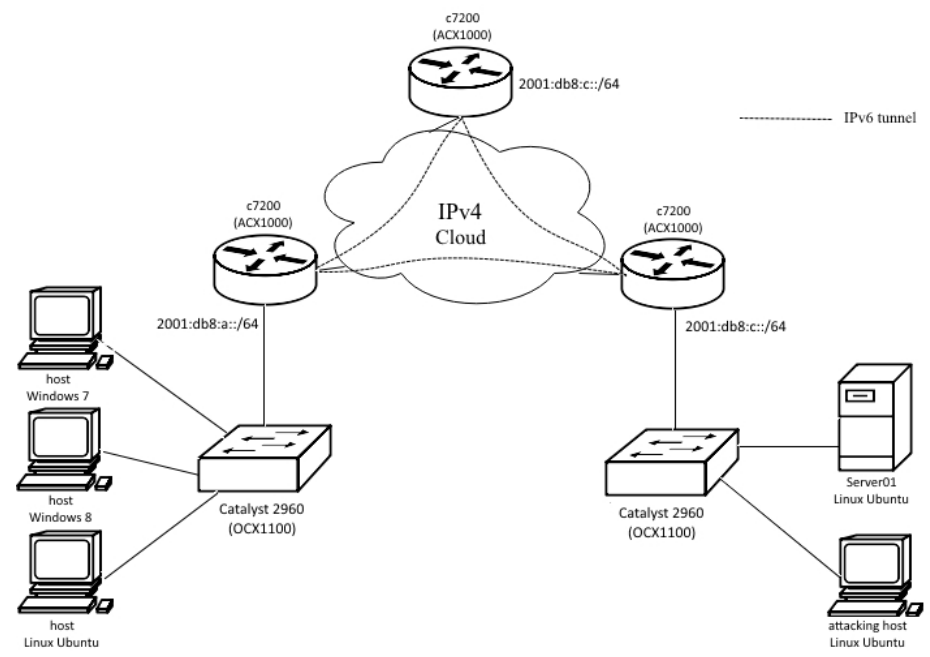

Рис. 2 - Топологія мережі для тестування зовнішніх атак

На пристрої Attacking host за допомогою Scapy формувалось повідомлення із інформацією прихованою в опціях PadN (' $\backslash 101$ ' - код символу 'A', ‘ $\backslash 102$ ' - код символу 'B') (рис. 3). На пристрої отримувача працювала програма Wireshark, що дала змогу побачити, що cформоване повідомлення прийшло неушкодженим (120 символів 'A' та 150 символів 'В') (рис. 4).

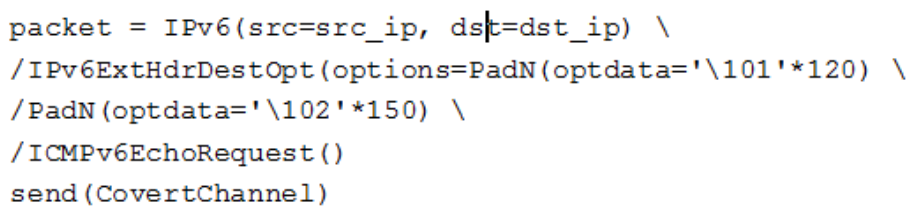

Рис. 3 - Повідомлення із прихованою інформаціею в опціях $\mathrm{PadN}$

Таким чином, зловмисник має можливість передавати приховану інформацію. Але більшу небезпеку представляють заголовки розширення, при умові, що на проміжних пристроях використовуються списки доступу. Проходження правил списку доступу не виконуеться до того, як не буде опрацьовано інформацію заголовку розширення. Як наслідок відбувається завантаження комп'ютера проміжного пристрою. На пристрої Attacking host за допомогою 


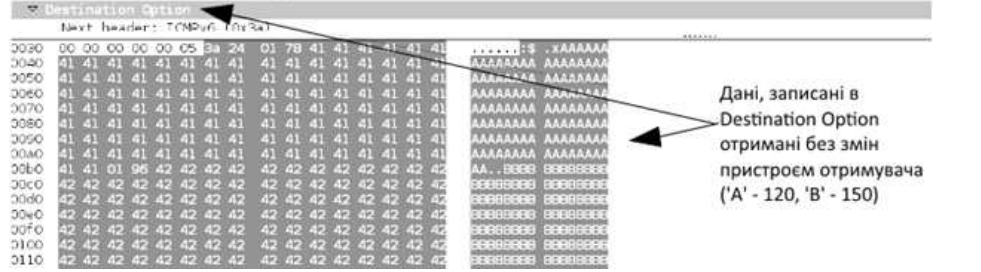

Рис. 4 - Отримане повідомлення із прихованою інформацією на пристрої отримувача

Scapy формувались повідомлення, показане на рис. 5. На рис. 6 та 7 показано завантаження комп'ютера при обробці даного повідомлення.

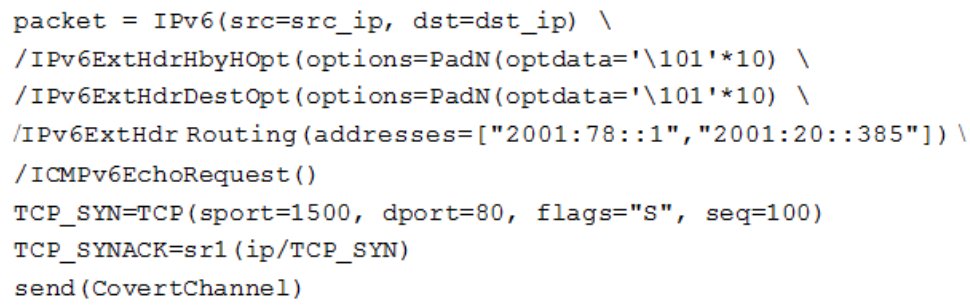

Рис. 5 - Повідомлення із послідовністю заголовків розширення

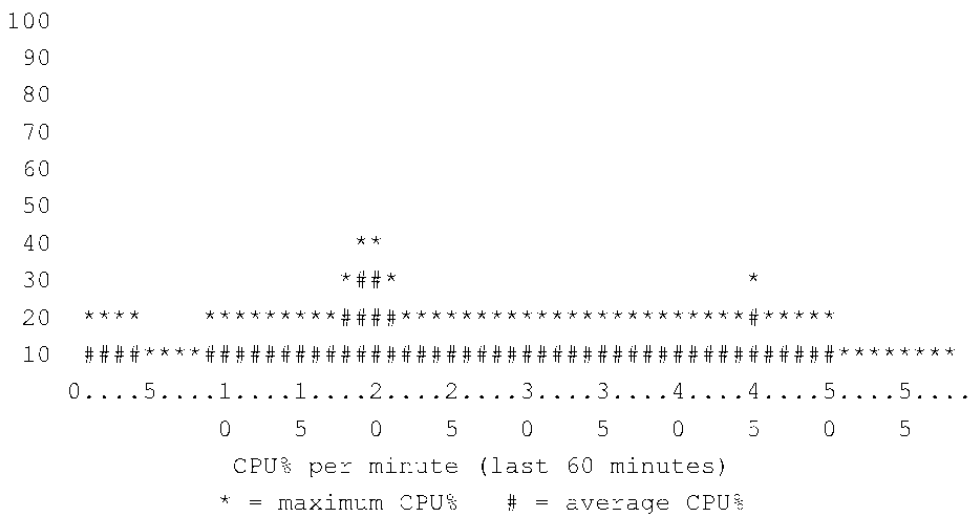

Рис. 6 - Середнє завантаження процесора маршрутизатора сіsco

На другому етапі, здійснювався пошук можливих заходів безпеки та перевірка їхньої ефективності. Заходи безпеки застосовувались для проміжних пристроїв. Для боротьби з розглянутими атаками можуть використовуватись списки доступу для фрільтрації 


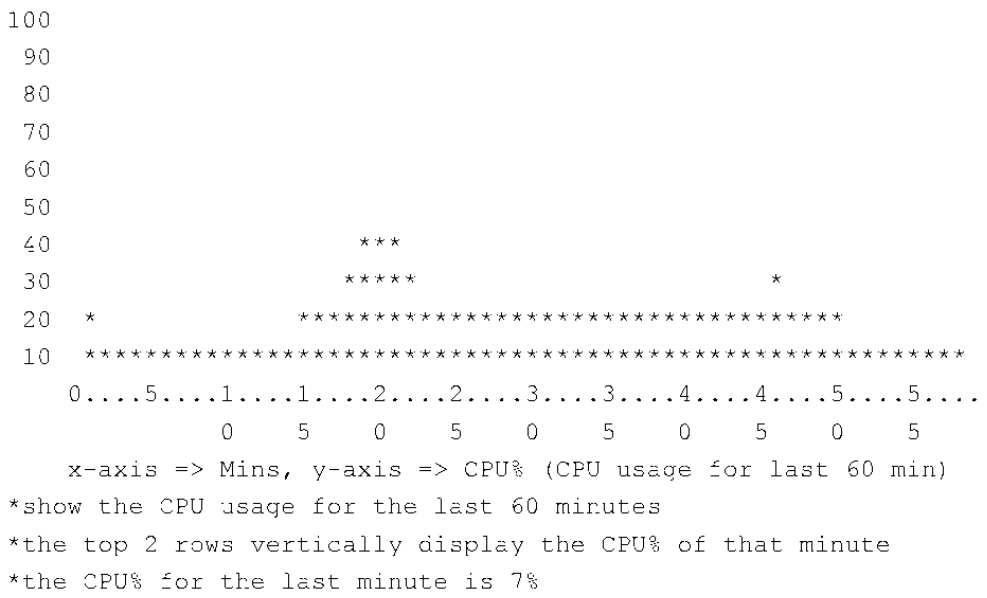

Рис. 7 - Середнє завантаження процесора маршрутизатора juniper

повідомлень із певним типом заголовків розширення. Але при цьому нефральсифіковані повідомлення, що використовують заголовки розширення, невірно обробляються, або взагалі відкидаються.

Останній етап роботи полягав у порівнянні ефективності заходів безпеки, доступних на використаному обладнанні. Результати представлені у табл. 1 .

\section{Висновки}

При тестуванні виявлено вразливості операційних систем обладнання проміжних пристроїв та кінцевих користувачів. Усунення виявлених недоліків потребуе глибокого знання специфріки роботи того чи іншого обладнання. В табл. 1 відображено виявлені вразливості обладнання та їх засоби попередження атак.

Варто відмітити, що вразливості, пов'язані з роботою ND, притаманні операційним системам кінцевих пристроїв. Unix-подібні системи мають засоби для попередження цих атак, але не всі вони працюють за замовчуванням. Що стосуеться Windows 7,8 , то деякі недоліки все ще не виправлені їх розробниками.

За результатами моделювання, довгий ланцюжок із заголовків розширення, що використовуються в IPv6 призводять до збільшення завантаження процесора на 9\%. При “затопленні” такими повідомленнями можна добитись відмови в обслуговуванні. Засоби для попередження даної атаки не завжди є ефективними.

Утворення петель в маршрутизації можливе для обладнання обох виробників, при використанні автоматичного тунелювання ISATAP та 6to4. 
Наявність засобів попередження атак обладнання cisco та juniper

\begin{tabular}{|c|c|c|c|c|c|c|c|c|c|c|c|}
\hline \multirow{3}{*}{ Атаки } & \multirow{3}{*}{ 薯 } & \multirow{3}{*}{ 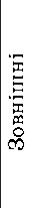 } & \multirow{3}{*}{ \& } & \multirow{3}{*}{ 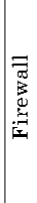 } & \multirow{3}{*}{ 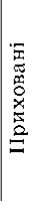 } & \multirow{3}{*}{ 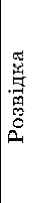 } & \multirow{3}{*}{ 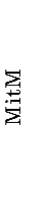 } & \multicolumn{4}{|c|}{ Наявність } \\
\hline & & & & & & & & \multicolumn{2}{|c|}{ вразливості } & \multicolumn{2}{|c|}{$\begin{array}{c}\text { засобів } \\
\text { попередженн } \\
\text { я }\end{array}$} \\
\hline & & & & & & & & cisco & $\begin{array}{c}\text { junip } \\
\text { er }\end{array}$ & cisco & $\begin{array}{c}\text { junip } \\
\text { er }\end{array}$ \\
\hline Розвідка в IPv6 мережі & $\mathrm{x}$ & $\mathrm{x}$ & & & & $\mathrm{x}$ & & + & + & + & + \\
\hline Перевантаження комутаторів & $\mathrm{x}$ & & $\mathrm{x}$ & $\mathrm{x}$ & & & & + & + & + & + \\
\hline Заголовки розширення & $\mathrm{x}$ & & $\mathrm{x}$ & $\mathrm{x}$ & $\mathrm{x}$ & & & + & + & - & $+/-$ \\
\hline $\begin{array}{l}\text { Петля в маршрутизації, при } \\
\text { використанні IPv6 тунелів }\end{array}$ & $\mathrm{x}$ & $\mathrm{x}$ & $\mathrm{x}$ & & & & & + & + & $+/-$ & $+/-$ \\
\hline Виявлення однакових адрес & $\mathrm{x}$ & & $\mathrm{x}$ & $\mathrm{x}$ & & & & + & + & - & - \\
\hline Підміна повідомлення RA & $\mathrm{x}$ & & $\mathrm{x}$ & $\mathrm{x}$ & & & $\mathrm{x}$ & - & - & + & + \\
\hline $\begin{array}{l}\text { «Затоплення» RA } \\
\text { повідомленнями }\end{array}$ & $\mathrm{x}$ & & $\mathrm{x}$ & & & & & - & - & + & + \\
\hline Підміна повідомлення NA & $\mathrm{x}$ & & $\mathrm{x}$ & $\mathrm{x}$ & & & $\mathrm{x}$ & - & - & + & + \\
\hline $\begin{array}{l}\text { «Затоплення» повідомленнями } \\
\text { NS }\end{array}$ & $\mathrm{x}$ & & $\mathrm{x}$ & & & & & - & - & - & - \\
\hline Вичерпування простору адрес & $\mathrm{x}$ & & $\mathrm{x}$ & & & & & - & - & + & + \\
\hline Підміна DHCPv6 сервера & $\mathrm{x}$ & & $\mathrm{x}$ & & & & $\mathrm{x}$ & - & - & + & + \\
\hline
\end{tabular}

Заходи з попередження розглянутих атак в тій, чи іншій мірі реалізовано на обладнанні обох виробників. Але деякі атаки залишили без уваги, можливо, з огляду на те, що для них такі заходи повинні бути реалізованими на кінцевих пристроях.

Тестова лабораторія дає можливість в повній мірі виконати моделювання мережі потрібної конфігурації, а у поєднанні із утилітою для створення та редагування мережевих пакетів, дозволяє перевірити поведінку обладнання у разі виникнення мережевих атак різних типів.

Вразливості, виявлені в ході дослідження, перевірено на базі обладнання cisco IOS та juniper junOS. Тестування показано, що якість інструментів по усуненню цих недоліків унеможливлює проведення розглянутих мережевих атак.

\section{Список використаних джерел}

1. IPv6 Readiness in the Communication Service Provider Industry. An Incognito Sof tware Report, April 2014, 18 p.

2. Santosh Naidu P1, Amulya Patcha, IPv6: Threats Posed By Multicast Packets, Extension Headers and Their Counter Measures. IOSR Journal of Computer Engineering (IOSR-JCE), Nov. - Dec. 2013, 66-75 p. 
3. T. Narten, E. Nordmark, W. Simpson, H. Soliman, Neighbor Discovery for IP version 6 (IPv6). Specification. RFC 4861, September 2007

4. Gabi Nakibly Michael Arov "Routing Loop Attacks using IPv6 Tunnels"- 7 USENIX Association Berkeley, CA, USA, 2009, 7 p.

5. Sander Degen, Arjen Holtzer Testing the security of IPv6 implementations - Nederland's, March 2014, 42 p.

Отримано 16.04.2015 p. 